7. Boyce JM. Increasing prevalence of methicillin-resistant Staphylococcus aureus in the United States. Infect Control Hosp Epidemiol 1990;11:639-642.

8. Voss A, Milatovic D, Wallrauch-Schwarz C, Rosdahl VT, Braveny I. Methicillin-resistant Staphylococcus aureus in Europe. Eur J Clin Microbiol Infect Dis 1994;13:50-55.

9. Oguri T. The incidence and antimicrobial susceptibility of clinical isolates of MRSA from 1988 to 1990 , from the results of 26 clinical laboratories in Tokyo and the surrounding area. Jap J Clin Med 1992;50:952-960.

10. Vincent JL, Bihari DJ, Suter PM, Bruining HA, White J, Nicolas-Chanoin $\mathrm{MH}$, et al. The prevalence of nosocomial infection in intensive care units in Europe. Results of the European Prevalence of Infection in Intensive Care (EPIC) Study. EPIC International Advisory Committee. JAMA 1995;274:639-644.

11. Vandenbroucke-Grauls C. Management of methicillin-resistant Staphylococcus aureus in The Netherlands. Rev Med Microbiol 1998; 9:109-116.

12. Hanifah YA, Hiramatsu $\mathrm{K}$, Yokota $\mathrm{T}$. Characterization of methicillinresistant Staphylococcus aureus associated with nosocomial infection in the University Hospital, Kuala Lumpur. I Hosp Infect 1992;21:15-28.

13. Gales AC, Jones RN, Pfaller MA, Gordon KA, Sader HS. Two-year assessment of the pathogen frequency and antinicrobial resistance patterns among organisms isolated from skin and soft tissue infections in Latin American hospitals: results from the SENTRY antimicrobial surveillance program, 1997-98. SENTRY Study Group. International Journal of Infectious Diseases 2000;4:75-84.

14. Geyid A, Lemeneh Y. The incidence of methicillin-resistant Staphylococcus aureus strains in clinical specimens in relation to their $\beta$ lactamase producing and multiple-drug resistance properties in Addis Ababa. Ethiop Med J 1991;29:149-161.

15. Hart CA, Kariuki S. Antimicrobial resistance in developing countries. BMJ 1998;317:647-650.

16. National Committee for Clinical Laboratory Standards. Performance Standards for Antimicrobial Disk Susceptibility Tests. Approved standard M2-A5. NCCLS: Villanova, PA; 1993.

17. National Committee for Clinical Laboratory Standards. Methods for Dilution Antimicrobial Susceptibility Tests for Bacteria That Grow Aerobically. Approved standard M7-A3. NCCLS; Villanova, PA: 1993.

18. Panlilio AI, Culver DH, Gaynes RP, Banerjee S, Henderson TS, Tolson JS, et al. Methicillin-resistant Staphylococcus aureus in US hospitals, 1975-1991. Infect Control Hosp Epidemiol 1992;13:582-586.

19. Lowy FD. Staphylococcus aureus infections. N Engl J Med 1998;339:520-532.

20. Speller DCE, Johnson AP, James D, Marples RR, Charlett A, George RC. Resistance to methicillin and other antibiotics in isolates of Staphylococcus aureus from blood and cerebrospinal fluid, England and Wales, 1989-95. Lancet 1997;350:323-325.

21. Mayor S. England sets standards to reduce hospital acquired infection. BMJ 1999;319:1392.

22. Linnemann CC, Moore P, Staneck JL, Pfaller MA. Reemergence of epidemic methicillin-resistant Staphylococcus aureus in a general hospital associated with changing staphylococcal strains. Am $J$ Med 1991;91 (suppl 3B):238-344.

23. Nettleman MD, Trilla A, Fredrickson M, Pfaller MA. Assigning responsibility: using feedback to achieve sustained control of methicillin resistant Staphylococcus aureus. Am J Med 1991;91(suppl 3B):228-232.

24 Layton MC, Hierholzer WJ, Patterson JE. The evolving epidemiology of methicillin-resistant Staphylococcus aureus at a university hospital. Infect Control Hosp Epidemiol 1995;16:12-17.

25. Strausbaugh LJ, Jacobson C, Sewell DL, Potter S, Ward TT. Methicillinresistant Staphylococcus aureus in extended-care facilities: experiences in a Veterans Affairs nursing home and a review of the literature. Infect Control Hosp Epidemiol 1991;12:36-45.

26. Coello R, Jimenez J, Garcia M, Arroyo P, Minguez D, Fernandez C, et al. Prospective study of infection, colonization and carriage of methicillinresistant Staphylococcus aureus in an outbreak affecting 990 patients. Eur J Clin Microbiol Infect Dis 1994;13:74-81.

27. Longfield JN, Townsend TR, Cruess DF, Stephen M, Bishop C, Bolyard E, et al. Methicillin-resistant Staphylococcus aureus (MRSA): risk and outcome of colonized vs infected patients. Infect Control 1985;6:445-450.

28. Myers JP, Linnemann CC. Bacteraemia due to methicillin-resistant Staphylococcus aureus. I Infect Dis 1982;145:532-536.

29. French GL, Cheng AF, Ling JM, Mo P, Donnan S. Hong Kong strains of methicillin-resistant and methicillin-sensitive Staphylococcus aureus have similar virulence. $J$ Hosp Infect 1990;15:117-125.

30. Harbarth S, Rutschmann O, Sudre P, Pittet D. Impact of methicillin resistance on the outcome of patients with bacteremia caused by Staphylococcus aureus. Arch Intern Med 1998;158:182-189.

31. Romero-Vivas J, Rubio M, Fernandez C, Picazo JJ. Mortality associated with nosocomial bacteremia due to methicillin-resistant Staphylococcus aureus. Clin Infect Dis 1995;21:1417-1423.

32. Conterno LO, Wey SB, Castelo A. Risk factors for mortality in Staphylococcus aureus bacteremia. Infect Control Hosp Epidemiol 1998;19:32-37.

33. Hiramatsu K, Hanaki $H$, Ino $T$, Yabuta $K$, Oguri $T$, Tenover FC. Methicillin-resistant Staphylococcus aureus clinical strain with reduced vancomycin susceptibility. I Antimicrob Chemother 1997;40:135-136.

34. Hiramatsu K, Aritaka N, Hanaki H, Kawasaki S, Hosoda Y, Hori S, et al. Dissemination in Japanese hospitals of strains of Staphylococcus aureus heterogeneously resistant to vancomycin. Lancet 1997 350:1670-1673.

35. Smith TL, Pearson ML, Wilcox KR, Cruz C, Lancaster MV, RobinsonDunn B, et al. Emergence of vancomycin resistance in Staphylococcus aureus. Glycopeptide-Intermediate Staphylococcus aureus Working Group. N Engl J Med 1999;340:493-501.

36. Tenover FC. Implications of vancomycin-resistant Staphylococcus aurews. J Hosp Infect 1999;43(suppl):3-7.

37. Centers for Disease Control and Prevention. Interim guidelines for pre vention and control of staphylococcal infection associated with reduced susceptibility to vancomycin. MMWR 1997;46:626-628.

\title{
New Agents Cause Nosocomial Fungemia
}

Gina Pugliese, RN, MS Martin S. Favero, $\mathbf{P h D}$

The primary cause of nosocomial fungemia has been Candida species, but increasingly molds and other yeasts are being implicated in disease. Exophiala jeanselmei and members of the genus Rhinocladiella are dematiaceous molds, which have been associated infrequently with systemic infection and have not been described as causes of fungemia. Nucci and coinvestigators from Hospital Universitario Clementino Fraga Filho, Universidade Federal do Rio de Janeiro,
Brazil, recently reported the occurrence of 23 cases of fungemia due to these organisms over a 10 -month period. They also describe the clinical characteristics of patients and outcomes.

The majority of patients were immunosuppressed; 21 (91\%) of 23 had received blood products, and $78 \%$ had a central venous catheter. All patients had at least one manifestation of fever, but only 1 patient had signs or symptoms suggesting deep-seated infection. Antifungal therapy was given to 19 of the 23 patients; of those who did not receive therapy, 3 died prior to the culture result, and 1 had been discharged without therapy.
Antifungal susceptibility of the organisms showed activity of amphotericin B, itraconazole, and the new triazole antifungals voriconazole and posaconazole. E jeanselmei and Rhinocladiella species are potential causes of nosocomial fungemia and may be associated with systemic infection.

FROM: Nucci M, Akiti T, Barreiros G, Silveira F, Revankar SG, Sution DA, et al. Nosocomial fungemia due to Exophiala jeanselmei var. jeanselmei and a Rhinocladiella species: newly described causes of bloodstream infection. $J$ Clin Microbiol 2001;39:514-518. 